A RCHIWA, BIBLIOTEKI

I MUZEA KOŚCIELNE 110 (2018)

https://doi.org/10.31743/abmk.2018.110.17

KS. MICHAŁ SOŁOMIENIUK* - POZNAŃ

\title{
SPUŚCIZNA PO PRYMASIE STEFANIE KARDYNALE WYSZYŃSKIM W ARCHIWUM ARCHIDIECEZJALNYM W GNIEŹNIE. ZAWARTOŚĆ I STAN OPRACOWANIA
}

\section{Uwagi wstępne}

Informacja o zawartości zasobu, pozostawionego po prymasie S. Wyszyńskim wydaje się bardzo konieczna, gdyż badacze, próbujący dotrzeć do konkretnych dokumentów czy zapisków, nie wiedzą, gdzie należy ich szukać. Tymczasem $W y$ szynsciana znajdują się zarówno w Warszawie (w trzech miejscach: w Archiwum Archidiecezjalnym, w postulacji procesu beatyfikacyjnego i w Instytucie Prymasowskim Stefana Kardynała Wyszyńskiego), jak i w Gnieźnie.

W zasobie Archiwum Archidiecezjalnego w Gnieźnie znajduje się pokaźna grupa archiwaliów po Prymasie Tysiąclecia. Dokumenty dotyczące zarządu archidiecezją gnieźnieńską z lat 1948-1981 powstały w Gnieźnie i zostały włączone do Archiwum Kurii Metropolitalnej ${ }^{1}$. Pozostałe 8 metrów bieżących akt zasadniczo nie zostało wytworzonych w Gnieźnie, a w Warszawie. Decyzja o przekazywaniu przynajmniej niektórych archiwaliów właśnie tutaj, należała do samego prymasa S. Wyszyńskiego. Archiwalia te zostały podzielone wstępnie na dwie części: spuściznę i akta, które trafią do zespołu Archiwum Prymasa Polski (APP). Zespół ten obejmował do tej pory archiwalia kardynałów Edmunda Dalbora i Augusta Hlonda. Trzeba tu dodać, że archiwalia po prymasie A. Hlondzie są bardzo różnorodne i obejmują m.in. zaproszenia i drobne druki, a nawet menu z uroczystych przyjęć.

* Ks. Michał Sołomieniuk - dr nauk humanistycznych w zakresie literaturoznastwa (Pontificium Institutum Altioris Latinitatis, Rzym); dyplomowany paleograf i archiwista; afiliowany przy Wydziale Historycznym Uniwersytetu Adama Mickiewicza w Poznaniu; dyrektor Archiwum Archidiecezjalnego w Gnieźnie; e-mail: solomieniuk@gmail.com

ORCID 0000-0002-3702-8096

${ }^{1}$ Zespół archiwalny pod nazwą Archiwum Kurii Metropolitalnej (AAG AKM) dzieli się na trzy działy: generalia (AKM I), parafie (AKM II) i personalia (AKM III); jest inwentaryzowany na bieżąco, a poszczególne jednostki w dziale I i II otrzymują hasła rzeczowe, dzięki którym można szybko odnaleźć interesujący badacza rodzaj akt. Archiwalia z czasów prymasa S. Wyszyńskiego dotyczące zarządu archidiecezją gnieźnieńską są siłą rzeczy rozproszone w tych trzech działach. 
Tak szerokie rozumienie akt urzędowych prymasa weźmiemy pod uwagę przy porządkowaniu archiwaliów Prymasa Tysiąclecia. Postanowiliśmy na razie zaliczyć do spuścizny prymasa Wyszyńskiego zapiski Pro memoria (oryginalne rękopisy i maszynopisy), varia (dokumentacja medyczna, zapiski duchowe, sprawozdanie z rozmowy z Bolesławem Bierutem), oraz tzw. Kazania Prymasa Polski. Decyzja o zaliczeniu kolejnych archiwaliów do spuścizny lub do APP zapadnie później. Na pewno trafią do zespołu APP facultates benedicendi i dokumentacja dotycząca odpustów, której jest kilkadziesiąt teczek.

Spuścizna po kardynale prymasie Stefanie otrzymała sygnaturę AAG SP $392^{2}$.

\section{Pro memoria}

Spuściznę otwiera 28 jednostek - odręcznych zapisków Pro memoria, które trudno jednoznacznie zaliczyć do notatek prywatnych (margines prywatności w życiu Prymasa Tysiąclecia był ograniczony). Zawierają one bowiem bardzo dokładny opis przebiegu dnia prymasa, tematy kazań i wystąpień, relacje z odbytych rozmów. Rzadziej znajdujemy tam zapiski o charakterze rozważań duchowych ${ }^{3}$. Prymas miał zwyczaj umieszczania na początku zapisków w danym roku hasła/tematyki duszpasterskiej danego roku. W okresie uwięzienia (1953-1956) prymas umieszczał w nich dokumenty, które zaliczylibyśmy do wytworów kancelarii, np. odpisy listów do władz PRL. Luźne kartki, które mają zwykle format nieco mniejszy niż A5, trafiły do Gniezna zapakowane w kartonikowe obwoluty, mieszczące każda zwykle zapiski z jednego roku. Nie miały one żadnych sygnatur. Zapiski z lat 1953-1956 nie były połączone w roczniki, lecz ułożone były następująco:

Tabela 1. Dawny podział rękopisu Pro memoria za lata 1953-1956 i uwagi biograficzne.

\begin{tabular}{|c|c|c|}
\hline $\begin{array}{c}\text { Numeracja robocza } \\
\text { „tomiku” }\end{array}$ & Datacja zapisków & Uwagi \\
\hline 3 & $1.01 .-20.09 .1953 \mathrm{r}$. & $\begin{array}{c}\text { Prymas został aresztowany } \\
25.09 .1953 \mathrm{r} .\end{array}$ \\
\hline 4 & $25.09 .1953-30.10 .1955 \mathrm{r}$. & $\begin{array}{c}\text { Okres uwięzienia w Rywałdzie, } \\
\text { Lidzbarku Warmińskim i Prudni- } \\
\text { ku, 27.10.1955 r. - przeniesienie } \\
\text { do Komańczy }\end{array}$ \\
\hline 5 & $30.10 .1955-13.12 .1956 \mathrm{r}$. & $\begin{array}{c}\text { Okres uwięzienia w Komańczy } \\
\text { oraz po uwolnieniu w dniu } \\
28.10 .1956 \mathrm{r} .\end{array}$ \\
\hline
\end{tabular}

${ }^{2}$ Skrót AAG oznacza Archiwum Archidiecezjalne w Gnieźnie.

${ }^{3}$ Pod datą 1 stycznia 1980 r. prymas pisał: „Czas mija - Bóg trwa; kalendarz Go nie obowiązuje. Chrystus wpisał się w dzieje człowieka, ale przekracza granice czasu - wprowadza człowieka do swojego wymiaru trwania ponadczasowego. Wszystko jako szata zwietrzeje, Ty zaś pozostajesz zawsze i lata Twoje nie ustają. Człowiek, brat Syna Człowieczego, uczestniczy w Jego kalendarzu. Przez wiarę stajemy się ponadczasowi”; AAG SP 392/27, s. 1.

${ }^{4}$ Rok 1981: „VI Rok Modlitwy Dziękczynnej za sześć wieków pobytu Obrazu Matki Bożej na Jasnej Górze (1982). Misyjny Rok Nawiedzenia Warszawy”; AAG SP 392/28, s. 1. 
Pro memoria zostały sfotografowane na potrzeby wydania krytycznego w takich zespołach kartek, włożonych w obwoluty, w jakich dotarły kilkadziesiąt lat temu do Gniezna. Obecnie zostały podzielone na następujące jednostki:

Tabela 2. Obecny podzial oryginalnych zapisków Pro memoria.

\begin{tabular}{|c|c|c|c|}
\hline $\begin{array}{c}\text { Kolejne } \\
\text { sygnatury } \\
\text { w obrębie SP } \\
392\end{array}$ & $\begin{array}{l}\text { Zakres } \\
\text { czasowy }\end{array}$ & Liczba kart & Uwagi \\
\hline 1 & $\begin{array}{c}22.10 .1948 \\
\text { do } \\
22.02 .1949\end{array}$ & 40 & \\
\hline 2 & $1952 \mathrm{r}$. & 536 & Tytuł ręką prymasa: „Brevi manu Pro memoria 1952” \\
\hline 3 & $1953 \mathrm{r}$. & 384 & \\
\hline 4 & $1954 \mathrm{r}$. & 79 & ostatnie 7 kart: $\mathrm{mps}$ \\
\hline 5 & $1955 \mathrm{r}$. & 90 & kilkanaście insertów \\
\hline 6 & $\begin{array}{c}1956 \mathrm{r} . \\
(\operatorname{od} 11.03)\end{array}$ & 90 & $\begin{array}{l}\text { Na końcu relacja ks. W. Padacza } \mathrm{z} \text { aresztowania } \\
\text { prymasa (mps) }\end{array}$ \\
\hline 7 & $1957 \mathrm{r}$. & 559 & $\begin{array}{l}\text { Na końcu notatki z Pro memoria, czynione ołów- } \\
\text { kiem inną ręką - } 11 \text { kart z cienkiego papieru, ozna- } \\
\text { czone obecnie literami od A do L. }\end{array}$ \\
\hline 8. & $1958 \mathrm{r}$. & 446 & $\begin{array}{l}\text { Na końcu dodano notatki z Pro memoria, czynione } \\
\text { ołówkiem inną ręką }-7 \text { kart z cienkiego papieru, } \\
\text { oznaczone obecnie literami od A do G. }\end{array}$ \\
\hline 9. & $1959 \mathrm{r}$. & 388 & \\
\hline 10. & $1960 \mathrm{r}$. & 385 & \\
\hline 11. & $1961 \mathrm{r}$. & 314 & \\
\hline 12. & $1962 \mathrm{r}$. & 436 & \\
\hline 13. & $1963 \mathrm{r}$. & 452 & \\
\hline 14. & $1964 \mathrm{r}$. & 464 & \\
\hline 15. & $1965 \mathrm{r}$. & 504 & \\
\hline 16. & $1966 \mathrm{r}$. & 546 & \\
\hline 17. & $1967 \mathrm{r}$. & 436 & \\
\hline 18. & $1968 \mathrm{r}$. & 565 & $\begin{array}{l}\text { k. 564: list niezidentyfikowanej osoby do prymasa; } \\
\text { k. 565: prośba w j. francuskim o audiencję u prymasa }\end{array}$ \\
\hline 19. & $1969 \mathrm{r}$. & 552 & \\
\hline 20. & $1970 \mathrm{r}$. & 550 & \\
\hline 21. & $1973 \mathrm{r}$. & 746 & k. A (dodatkowa): notatka ks. Aleksandrowicza \\
\hline 22. & $1975 \mathrm{r}$. & 677 & \\
\hline 23. & $1976 \mathrm{r}$. & 631 & \\
\hline 24. & $1977 \mathrm{r}$. & 633 & \\
\hline 25. & $1978 \mathrm{r}$. & 691 & \\
\hline 26. & $1979 \mathrm{r}$. & 553 & \\
\hline 27 & $1980 \mathrm{r}$. & 636 & \\
\hline 28 & $1981 \mathrm{r}$. & $186^{\mathrm{a}}$ & \\
\hline
\end{tabular}

a Zapisy kończą się na 12.05; dodatkowa kartka z uwagami ks. M. Aleksandrowicza. 
W zasobie Archiwum Archidiecezjalnego w Gnieźnie brakuje oryginałów Pro memoria $\mathrm{z}$ lat: 1971, 1972 i 1974. Prawdopodobnie znajdują się one w archiwum Instytutu Kardynała Stefana Wyszyńskiego w Warszawie, na Choszczówce.

Osobnej uwagi wymagają inserty. Zaliczamy do nich wyłącznie kartki/dokumenty, umieszczone przez prymasa współcześnie do powstawania zapisków lub krótko później. Pozostałe kartki, dołożone na etapie redakcji, nazywamy dodatkami. Te inserty, które można datować, pozostały na swoim prawdopodobnie oryginalnym miejscu między innymi kartkami. W przeciwnym wypadku zostały umieszczone na końcu danej jednostki. Zasadniczo inserty spotykamy w zapiskach z okresu uwięzienia. Są to zwykle listy, kierowane do prymasa od członków rodziny i odpisy listów prymasa do różnych osób.

Tabela 3. Inserty w oryginalnych zapiskach Pro memoria.

\begin{tabular}{|c|c|c|c|c|}
\hline L. p. & $\begin{array}{c}\text { Sygnatura } \\
\text { w obrębie } \\
\text { SP } 392\end{array}$ & Treść insertu & Datacja & $\begin{array}{c}\text { Strona / } \\
\text { strony }\end{array}$ \\
\hline 1 & 2 & 3 & 4 & 5 \\
\hline 1. & 4 & List od ojca (cenzurowany) & 3.04 .1954 & k. 10 \\
\hline 2. & 4 & List od ojca & 8.06 .1954 & k. 19 \\
\hline 3. & 4 & List od ojca & 6.02 .1954 & k. 72 \\
\hline 4. & 4 & $\begin{array}{l}\text { Kopia listu prymasa do „Prezesa Rządu } \\
\text { PRL” (mps) }\end{array}$ & 2.07 .1954 & k. $73-79$ \\
\hline 5. & 5 & list siostry Stanisławy & $12.1954 / 1.1955$ & k. 2 \\
\hline 6. & 5 & $\begin{array}{l}\text { List od siostry Stanisławy, } \\
\text { brata Tadeusza i ojca }\end{array}$ & 10.02 .1955 & k. 6 \\
\hline 7. & 5 & List od ojca & 23.05 .1955 & k. 31 \\
\hline 8. & 5 & List od ojca & 30.06 .1955 & k. 32 \\
\hline 9. & 5 & List siostry Stanisławy & 24.05 .1955 & k. 33 \\
\hline 10. & 5 & List siostry Stanisławy & 29.06 .1955 & k. 34 \\
\hline 11. & 5 & $\begin{array}{l}\text { Telegram od bpa Klepacza - zapowiedź } \\
\text { wizyty } 2.11\end{array}$ & 29.09 .1955 & k. 83 \\
\hline 12. & 5 & Inwentarz rzeczy osobistych Prymasa & 1955 & k. $84,85,86$ \\
\hline 13. & 5 & List siostry Stanisławy & $30-31.10 .1955$ & k. 87 \\
\hline 14. & 5 & $\begin{array}{l}\text { Kopie listów do: bpa Franciszka Bardy, } \\
\text { bpa Michała Klepacza, ojca, siostry Sta- } \\
\text { nisławy, bpa Zygmunta Choromańskiego }\end{array}$ & 30.10 .1955 & k. $88-90^{\mathrm{a}}$ \\
\hline 15. & 6 & $\begin{array}{l}\text { Relacja ks. Władysława Padacza o aresz- } \\
\text { towaniu Prymasa } 25.09 .1953 \mathrm{r} \text {. }\end{array}$ & 1953-1956 (?) & k. 87,88 \\
\hline 16. & 6 & List dr St. Wąsowicza & 7.08 .1956 & k. $89-90$ \\
\hline 17. & 12 & $\begin{array}{l}\text { Kartka z pytaniami dot. soboru, zadany- } \\
\text { mi prymasowi na spotkaniu duszpaster- } \\
\text { skim } 30.12\end{array}$ & 1962 & k. 436 \\
\hline
\end{tabular}

a Po k. 90 włożono trzy obrazki święte, dotąd włożone po k. 34 i oznaczone numerami 34a, 34b, 34c (prymicyjny ks. Rudolfa Krupopa z 1960, jubileuszowy ks. Jerzego Szczeponika z 1963, obrazek z modl. do języka św. Antoniego - wł./łac.). Jak wynika z datacji obrazków, trafiły one do Pro memoria w latach 60. XX wieku. 


\begin{tabular}{|c|c|l|c|c|}
\hline $\mathbf{1}$ & $\mathbf{2}$ & \multicolumn{1}{|c|}{$\mathbf{3}$} & $\mathbf{4}$ & $\mathbf{5}$ \\
\hline 18. & 17 & $\begin{array}{l}\text { Notatki z wystąpienia prymasa } \\
\text { (inna ręka) }\end{array}$ & 1967 & k. 435 \\
\hline 19. & 17 & $\begin{array}{l}\text { Mps ,Notatka ZJP” [ks. Z. Peszkowskie- } \\
\text { go] - ze spotkania w Rzymie dot. Polonii } \\
\text { Amerykańskiej, podpisana przez bpa } \\
\text { W. Rubina }\end{array}$ & 1967 & k. 436 \\
\hline 20. & 18 & $\begin{array}{l}\text { List prywatny od Andrzeja } \\
\text { (bez nazwiska) }\end{array}$ & 26.08 .1968 & k. 564 \\
\hline 21. & 18 & $\begin{array}{l}\text { Prośba o audiencję dla grupy księży } \\
\text { i świeckich z Paryża }\end{array}$ & 17.08 .1968 & k. 565 \\
\hline 22. & 19 & $\begin{array}{l}\text { Zarys zagadnień na spotkanie inteligen- } \\
\text { cji narodowej z prymasem (mps) }\end{array}$ & $\begin{array}{c}\text { przed } \\
22.02 .1969\end{array}$ & k. 551 \\
\hline 23. & 19 & Telegram z Wiednia & 6.10 .1969 & k. 552 \\
\hline 24. & 21 & $\begin{array}{l}\text { Lista kardynałów i biskupów, uczestni- } \\
\text { ków uroczystości 500-lecia urodzin } \\
\text { M. Kopernika we Fromborku }\end{array}$ & 17.06 .1973 & k. 745,746 \\
\hline
\end{tabular}

Zapiski Pro memoria noszą ślady prac redakcyjnych w Warszawie i archiwizacyjnych w Gnieźnie. Do Gniezna trafiały partiami jeszcze za życia autora i z jego woli. Pod datą 28.03.1973 r. prymas zapisał: „Ks. Dyr. W. Zientarski na wieczerzy. Otrzymuje dla Archiwum Prymasowskiego dalsze partie zapisków moich 'pro memoria' - rękopisy - maszynopisy"'. Rzecz działa się w Gnieźnie $\mathrm{w}$ siedzibie prymasa. $\mathrm{Z}$ tej krótkiej notatki wynika, że rękopisy były najpierw przepisywane na maszynie, a następnie przekazywane osobiście przez ordynariusza do Archiwum Archidiecezjalnego w Gnieźnie, które sam prymas zwał często Archiwum Prymasowskim. Na obwolucie rocznika 1952 znajduje się odręczna uwaga: ,przepisane na maszynie w 3 egz”.

Prace nad rękopisami (porównywanie rękopisów z maszynopisami, zaznaczanie brakujących kartek, foliacja itp.) nastąpiły w 2. połowie lat 80 . XX wieku. Oto na starej obwolucie oznaczonej roboczym numerem 3 czytamy: „Zapiski 1.I - 20.IX.1953 / Odczytano - skolacjonowano kwiecień 1988 / Ks. Władysław Zientarski" ${ }^{6}$. Po śmierci ks. Zientarskiego, prace te kontynuował nowy dyrektor archiwum, ks. Marian Aleksandrowicz. Z jego notatek na teczkach z rocznikami 1972 i 1973 dowiadujemy się, że kolacjonowanie prowadził on z pomocą Katarzyny Michalskiej z Instytutu Prymasowskiego. Jak wspomniałem wyżej, rocznik 1975 dotarł do Gniezna niekompletny, z zapiskami tylko od 1 czerwca. Ks. Aleksandrowicz na teczce napisał pod datą 23.11.1992: „Gdzie znajduje się rękopis z okresu 1 I - 30 VI 1973 nie wiadomo. Pani Katarzyna Michalska z Instytutu również nie potrafi udzielić informacji”" . Aktualnie te brakujące zapiski są w po-

\footnotetext{
${ }^{5}$ AAG SP 392/21, k. 172 b.

${ }^{6}$ AAG SP 392/3.

a Ta kartka najwidoczniej później się odnalazła, gdyż widnieje w rękopisie.

${ }^{7}$ AAG SP 392/22.
} 
siadaniu Archiwum Archidiecezjalnego w Gnieźnie, zatem musiały zostać później odnalezione.

Wszystkie „tomiki” (a przynajmniej ich większość) trafiały do Gniezna prawdopodobnie bez paginacji/foliacji. Numerowanie kart, jakie tu miało miejsce, nie obyło się bez licznych błędów, obecnie usuniętych.

Najwięcej braków ks. W. Zientarski wynotował w roczniku 1955 (obecnie SP 392/5):

Tabela 4. Braki w rękopisie Pro memoria za rok 1955.

\begin{tabular}{|l|l|}
\hline \multicolumn{1}{|c|}{ Miesiąc } & \multicolumn{1}{c|}{ Dzień } \\
\hline styczeń & $1,5,6,7,17,23$ \\
\hline luty & 1,4, \\
\hline marzec & $8,11,12,13,19,22,25$ (częściowo), 29 \\
\hline kwiecień & $3,4,7,8,11,12,18$ \\
\hline maj & $1,3,12,19$ \\
\hline lipiec & 16 \\
\hline sierpień & 1,3 (częściowo) \\
\hline wrzesień & 14,25 \\
\hline październik & $25,26,28$ (częściowo), 31 ${ }^{\mathrm{a}}$ \\
\hline
\end{tabular}

Poza datami: 17, 23 stycznia i 1 lutego zawsze jest informacja, że za dany dzień istnieje kopia maszynopisowa.

Braki w rękopisie z roku 1981 stwierdził ks. M. Aleksandrowicz. W 1993 roku zapisał on na dodatkowej kartce, umieszczonej z zapiskami z roku śmierci prymasa:

Wśród oryginałów brakuje 2 kart $137^{8}$ i $138^{9}$ obejmujących dzień 31 marca i 1 kwietnia. Pani Katarzyna Michalska uzupełniła ten brak odbitkami kserokopiowymi zrobionymi z posiadanych przez Instytut kserokopiami oryginału $^{10}$.

Jest to cenna uwaga: dowiadujemy się, że Instytut Prymasowski dysponuje kserokopiami całego rękopisu. Wykonano zatem „kopię z kopii” i przekazano do Gniezna. Obecnie kopie te są zintegrowane z manuskryptem.

Jednostki o sygnaturach SP 392/29 do 49 to maszynopisy - kopie Pro memoria. Oto zestawienie maszynopisów i odpowiadających im rękopisów:

Tabela 5. Porównanie zawartości rękopisu i maszynopisu Pro memoria.

\begin{tabular}{|c|c|c|}
\hline $\begin{array}{c}\text { Sygnatura rps } \\
\text { SP 392/.. }\end{array}$ & $\begin{array}{c}\text { Sygnatura mps } \\
\text { SP 392/.. }\end{array}$ & Zakres czasowy \\
\hline $\mathbf{1}$ & $\mathbf{2}$ & $\mathbf{3}$ \\
\hline 1 & 29 & $22.10 .1948-22.02 .1949$ \\
\hline 2 & 30 & 1952 \\
\hline
\end{tabular}

\footnotetext{
${ }^{8}$ Obecnie 143.

${ }^{9}$ Obecnie 144.

${ }^{10}$ AAG SP 392/28 (k. nlb.).
} 


\begin{tabular}{|c|c|c|}
\hline 1 & 2 & 3 \\
\hline 3 & 31 & Mps: $1.09-19.09 .1953 ;$ rps cały rok 1953 \\
\hline $3,4,5,6$ & 32 & Mps: $25.09 .1953-31.12 .1956$ \\
\hline 7 & 33 & 1957 \\
\hline 8 & 34 & 1958 \\
\hline 9 & 35 & 1959 \\
\hline 10 & 36 & 1960 \\
\hline 11 & 37 & 1961 \\
\hline 12 & 38 & 1962 \\
\hline 13 & 39 & 1963 \\
\hline 14 & 40 & 1964 \\
\hline 15 & 41 & 1965 \\
\hline 16 & 42 & 1966 \\
\hline 17 & 43 & 1967 \\
\hline 18 & 44 & 1968 \\
\hline 19 & 45 & 1969 \\
\hline 20 & 46 & 1970 \\
\hline brak & 47 & 1971 \\
\hline brak & $48^{\mathrm{a}}$ & 1972 \\
\hline 21 & 49 & 1973 \\
\hline brak & 50 & 1974 \\
\hline 22 & brak & 1975 \\
\hline 23 & brak & 1976 \\
\hline 24 & 52 & 1977 \\
\hline 25 & 53 & 1978 \\
\hline 26 & 54 & 1979 \\
\hline 27 & 55 & 1980 \\
\hline 28 & 56 & 1981 \\
\hline
\end{tabular}

Nie ma maszynopisu za rok 1975 (jest natomiast kserokopia rękopisu za miesiące styczeń-maj 1975 - SP 392/51) oraz 1976.

\section{VARIA}

Jednostka SP 392/57 nosi nazwę Ostatnia choroba Ojca i zawiera dokumentację medyczną z okresu 15.10.1976-28.05.1981 r., w tym elektrokardiogramy i zdjęcie rentgenowskie. Poza językiem polskim znajdujemy tam zapisy po łacinie i po włosku. Ta jednostka nie będzie zasadniczo udostępniana.

W kolejnej jednostce, SP 392/58, znajduje się Kalendarzyk łaski. Rywatd, Stoczek, Prudnik, Komańcza. Jest to maszynopis formatu A5 z wyjętymi z Pro memoria zapiskami ściśle duchowymi. Wbrew tytułowi kartki od 2 (pierwszej brak) do 263 obejmują okres od 2.01.1954 r. do 10.10.1956 r. a karty 264-281 również refleksje z lat 1958-1961. Na teczce widnieje naklejka: „I. egz. Rękopis u M[arii] O[końskiej]”.

\footnotetext{
${ }^{4} \mathrm{Na}$ teczce naklejka z napisem „brak rękopisu”.
} 
Zupełnie inny charakter ma jednostka SP 392/59. Jest to streszczenie Rozmowy z Prezydentem R.P. $w$ Belwederze $w$ dniu 3. II. 1951. Jednostronnie zapisane karty 1-106 o formacie A5 to rękopis; karty 107-130 to mps tej samej rozmowy w języku polskim (24 karty); k. 131-176 to mps z wersją włoską. Wersja włoska w kilku miejscach jest uboższa o całe akapity.

Jednostki o sygnaturach SP 392/60 do SP 392/172 noszą wspólną nazwę Kazania Prymasa Polski i są to maszynopisy, dużo rzadziej druki. Należy zaznaczyć, że nie są to wyłącznie kazania, ale wszelkie wystąpienia publiczne, a także przesłania, listy pasterskie itp. Pod względem redakcyjnym dzielą się one na: (1) autografy, (2) teksty autoryzowane, (2) notatki osób trzecich (zwykle pań z Instytutu Prymasowskiego), (3) wystąpienia spisane z taśmy magnetofonowej bez żadnej korekty, (4) teksty bez oznaczeń. Prymas rzadko przygotowywał kazania w całości na piśmie przed ich wygłoszeniem. Świadkowie potwierdzają, że kardynał S. Wyszyński korzystał z własnych notatek, z rozpisanym planem kazania i ewentualnymi cytatami. Jednak jedno przemówienie/kazanie ma dwie wersje: autoryzowaną oraz spisaną na podstawie notatek, głównie Marii Okońskiej, por. kazanie na poświęcenie kaplicy bpa Czerniaka w Gnieźnie, które dodatkowo oznaczono różnymi datami (31.01.1962 r. - tekst autoryzowany i 2.02.1962 r. - „,notatki Marysi") ${ }^{11}$. Kazania prymasa dotarły w dwu seriach, nazwanych od koloru teczek „serią szarą" i ,serią kolorową". Żadna z tych serii nie jest kompletna. Poniższa tabelka ukazuje zawartość tej części spuścizny:

Tabela 6. Zawartość zbioru Kazania Prymasa Polski w serii „szarej” i „kolorowej”

\begin{tabular}{|c|c|l|l|}
\hline L.p. & $\begin{array}{c}\text { Sygnatura } \\
\text { SP 392/.. }\end{array}$ & \multicolumn{1}{|c|}{ Seria } & \multicolumn{1}{|c|}{ Okres } \\
\hline $\mathbf{1}$ & $\mathbf{2}$ & $\mathbf{3}$ & \multicolumn{1}{|c|}{$\mathbf{1}$} \\
\hline 1. & 60 & szara & 1955-1956 r. \\
\hline 2. & 61 & szara & styczeń-kwiecień 1957 r. \\
\hline 3. & 62 & szara & maj-wrzesień 1957 r. \\
\hline 4. & 63 & szara & październik-grudzień 1957 r. \\
\hline 5. & 64 & szara & luty-lipiec 1958 \\
\hline 6. & 65 & szara & sierpień-grudzień 1958 \\
\hline 7. & 66 & szara & styczeń-maj 1959 r. ${ }^{\mathrm{a}}$ \\
\hline 8. & 67 & szara & czerwiec-sierpień 1959 r. \\
\hline 9. & 68. & szara & wrzesień-grudzień 1959 r. \\
\hline 10. & 69 & szara & styczeń-lipiec 1960 r. \\
\hline 11. & 70 & szara & sierpień-grudzień 1960 r. \\
\hline 12. & 71 & szara & styczeń-maj 1961 \\
\hline 13. & 72 & szara & czerwiec-wrzesień 1961 r. \\
\hline 14. & 73 & szara & październik-grudzień 1961 r. ${ }^{b}$ \\
\hline
\end{tabular}

${ }^{a}$ Na początku zestawienie kazań za cały rok 1959, pierwsze kazanie z 29.01 (brak pierwszych pięciu).

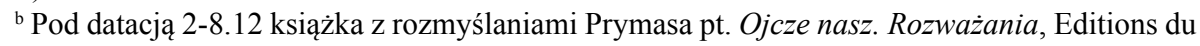
Dialogue: Paryż 1975 - nienumerowana łącznie z luzami.

${ }^{11}$ Por. AAG SP 392/74. 


\begin{tabular}{|c|c|c|c|}
\hline 1 & 2 & 3 & 4 \\
\hline 15. & 74 & szara & styczeń-marzec 1962 r. \\
\hline 16. & 75 & szara & kwiecień 1962 r. \\
\hline 17. & 76 & szara & maj-czerwiec 1962 r. \\
\hline 18. & 77 & szara & lipiec-sierpień 1962 r. \\
\hline 19. & 78 & szara & wrzesień 1962 r. \\
\hline 20. & 79 & szara & październik-grudzień 1962 r. \\
\hline 21. & 80 & szara & styczeń-marzec 1963 r. \\
\hline 22. & 81 & szara & kwiecień $1963 \mathrm{r}$. \\
\hline 23. & 82 & szara & maj-sierpień $1963 \mathrm{r}$. \\
\hline 24. & 83 & szara & wrzesień-grudzień $1963 \mathrm{r}$. \\
\hline 25. & 84 & szara & styczeń-luty 1964 r. \\
\hline 26. & 85 & szara & marzec-kwiecień $1964 \mathrm{r}$. \\
\hline 27. & 86 & szara & maj-czerwiec $1964 \mathrm{r}$. \\
\hline 28. & 87 & szara & lipiec-sierpień 1964 r. \\
\hline 29. & 88 & szara & wrzesień-grudzień 1964 r. \\
\hline 30. & 89 & szara & styczeń 1965 r. \\
\hline 31. & 90 & szara & luty-marzec $1965 \mathrm{r}$. \\
\hline 32. & 91 & szara & kwiecień 1965 r. \\
\hline 33. & 92 & szara & maj $1965 \mathrm{r}$. \\
\hline 34. & 93 & szara & czerwiec $1965 \mathrm{r}$. \\
\hline 35. & 94 & szara & lipiec-sierpień 1965 r. \\
\hline 36. & 95 & szara & wrzesień-grudzień $1965 \mathrm{r}$. \\
\hline 37. & 96 & szara & 1966 - uzupełnienia \\
\hline 38. & 97 & szara & 1967 - uzupełnienia \\
\hline 39. & 98 & szara & 1971, 1973 - uzupełnienia \\
\hline 40. & 99 & szara & luty-październik 1974 r. - uzupełnienia \\
\hline 41. & 100 & szara & listopad-grudzień $1974 \mathrm{r}$. \\
\hline 42. & 101 & szara & styczeń-marzec $1975 \mathrm{r}$. \\
\hline 43. & 102 & szara & kwiecień-lipiec 1975 r. \\
\hline 44. & 103 & szara & sierpień-wrzesień $1975 \mathrm{r}$. \\
\hline 45. & 104 & kolorowa & 16 maja - 30 grudnia $1956 \mathrm{r}$. \\
\hline 46. & 105 & kolorowa & styczeń-maj 1957 r. \\
\hline 47. & 106 & kolorowa & II poł. czerwca - I poł. września 1957 r. \\
\hline 48. & 107 & kolorowa & październik-grudzień 1957 r. \\
\hline 49. & 108 & kolorowa & styczeń-czerwiec $1958 \mathrm{r}$. \\
\hline 50. & 109 & kolorowa & lipiec-grudzień 1958 r. + spis \\
\hline 51. & 110 & kolorowa & styczeń-czerwiec (do 22) 1959 r. + spis \\
\hline 52. & 111 & kolorowa & czerwiec (od 19) - grudzień (do 27) 1959 r. + spis \\
\hline 53. & 112 & kolorowa & styczeń-lipiec 1960 r. + spis \\
\hline 54. & 113 & kolorowa & sierpień- grudzień 1960 r. + spis \\
\hline 55. & 114 & kolorowa & styczeń-kwiecień 1961 r. + spis \\
\hline 56. & 115 & kolorowa & maj-lipiec $1961 \mathrm{r} .+$ spis \\
\hline 57. & 116 & kolorowa & sierpień-grudzień 1961 r. + spis \\
\hline 58. & 117 & kolorowa & styczeń-kwiecień $1962+$ spis \\
\hline
\end{tabular}




\begin{tabular}{|c|c|c|c|}
\hline 1 & 2 & 3 & 4 \\
\hline 59. & 118 & kolorowa & maj-sierpień 1962 r. + spis \\
\hline 60. & 119 & kolorowa & wrzesień-grudzień $1962+$ spis \\
\hline 61. & 120 & kolorowa & marzec-sierpień $1962 \mathrm{r}^{\mathrm{a}}$ \\
\hline 62. & 121 & kolorowa & styczeń-marzec 1963 r. + spis \\
\hline 63. & 122 & kolorowa & kwiecień-sierpień 1963 r. + spis \\
\hline 64. & 123 & kolorowa & wrzesień-grudzień 1963 r. + spis \\
\hline 65. & 124 & kolorowa & styczeń-marzec 1964 r. + spis \\
\hline 66. & 125 & kolorowa & kwiecień-czerwiec (do 9) 1964 r. + spis ${ }^{\mathrm{b}}$ \\
\hline 67. & 126 & kolorowa & $\begin{array}{l}\text { czerwiec (od 10) - sierpień } 1964 \text { r. + spis kazań za } \\
\text { lipiec-grudzień (!) }\end{array}$ \\
\hline 68. & 127 & kolorowa & wrzesień-grudzień 1964 r. \\
\hline 69. & 128 & kolorowa & 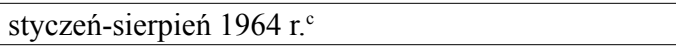 \\
\hline 70. & 129 & kolorowa & styczeń-marzec $1965 \mathrm{r}$. \\
\hline 71. & 130 & kolorowa & kwiecień-czerwiec 1965 r. + spis \\
\hline 72. & 131 & kolorowa & lipiec-grudzień 1965 r. + spis \\
\hline 73. & 132 & kolorowa & styczeń-marzec 1966 r. \\
\hline 74. & 133 & kolorowa & kwiecień-czerwiec $1966 \mathrm{r}$. \\
\hline 75. & 134 & kolorowa & czerwiec-wrzesień (do 19) 1966 r. \\
\hline 76. & 135 & kolorowa & wrzesień (od 20 ) - grudzień 1966 r. \\
\hline 77. & 136 & kolorowa & 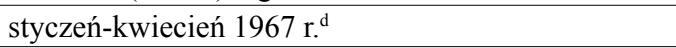 \\
\hline 78. & 137 & kolorowa & maj-sierpień $1967 \mathrm{r}^{\mathrm{e}}$ \\
\hline 79. & 138 & kolorowa & wrzesień-grudzień 1967 r. \\
\hline 80. & 139 & kolorowa & styczeń-kwiecień (do 14) $1968 \mathrm{r}$. \\
\hline 81. & 140 & kolorowa & kwiecień (od 14) - maj 1968 r. \\
\hline 82. & 141 & kolorowa & czerwiec-sierpień (do 14) 1968 r. \\
\hline 83. & 142 & kolorowa & sierpień (od 15) - wrzesień $1968 \mathrm{r}$. \\
\hline 84. & 143 & kolorowa & październik-grudzień 1968 r. \\
\hline 85. & 144 & kolorowa & styczeń-kwiecień (do 20) $1968 \mathrm{r}$. \\
\hline 86. & 145 & kolorowa & kwiecień (od 22) - maj $1968 \mathrm{r} .^{\mathrm{g}}$ \\
\hline 87. & 146 & kolorowa & czerwiec-sierpień (do 10) $1968 \mathrm{r}^{\mathrm{h}}$ \\
\hline 88. & 147 & kolorowa & sierpień (od 11) - wrzesień (do 1) 1968 r. \\
\hline 89. & 148 & kolorowa & wrzesień-grudzień $1968 \mathrm{r}$. \\
\hline 90. & 149 & kolorowa & styczeń-marzec 1970 r. \\
\hline 91. & 150 & kolorowa & kwiecień-maj (do 14) 1970 r. \\
\hline 92. & 151 & kolorowa & maj (od 17) - czerwiec $1970 \mathrm{r}$. \\
\hline
\end{tabular}

${ }^{a}$ Kazania i rozważania wygłoszone podczas dni skupienia Instytutu Prymasowskiego.

${ }^{\mathrm{b}}$ Spis doprowadzony do 30 czerwca (kazania od 10.06 znajdują się w kolejnej teczce); w spisie brakuje niektórych wystąpień, zawartych w teczce.

${ }^{c}$ Kazania i rozważania wygłoszone podczas dni skupienia Instytutu Prymasowskiego.

${ }^{d}$ Na okładce mylnie zaznaczono miesiące: I-VII.

${ }^{\text {e }} \mathrm{Na}$ okładce mylnie zaznaczono miesiące: VIII-XII.

${ }^{\mathrm{f}} \mathrm{Na}$ okładce mylnie zaznaczono miesiące: I-V.

g Na okładce mylnie zaznaczono miesiące: V-VIII.

${ }^{\text {h }} \mathrm{Na}$ okładce mylnie zaznaczono miesiące: IX-XII. 


\begin{tabular}{|c|c|c|c|}
\hline 1 & 2 & 3 & 4 \\
\hline 93. & 152 & kolorowa & lipiec-sierpień $1970 \mathrm{r}$. \\
\hline 94. & 153 & kolorowa & wrzesień $1970 \mathrm{r}$. \\
\hline 95. & 154 & kolorowa & październik-grudzień 1970 r. \\
\hline 96. & 155 & kolorowa & styczeń-marzec 1971 r. \\
\hline 97. & 156 & kolorowa & kwiecień-maj 1971 r. \\
\hline 98. & 157 & kolorowa & czerwiec-sierpień $1971 \mathrm{r}$. \\
\hline 99. & 158 & kolorowa & wrzesień-listopad (do 16-go) $1971 \mathrm{r}$. \\
\hline 100. & 159 & kolorowa & $\begin{array}{l}\text { miesiące: listopad (od 17-go) - grudzień (do 25-go) } \\
1971 \mathrm{r} \text {. }\end{array}$ \\
\hline 101. & 160 & kolorowa & styczeń-marzec 1972 r. \\
\hline 102. & 161 & kolorowa & kwiecień-czerwiec 1972 r. \\
\hline 103. & 162 & kolorowa & lipiec-wrzesień 1972 r. \\
\hline 104. & 163 & kolorowa & październik-grudzień 1972 r. \\
\hline 105. & 164 & kolorowa & styczeń-marzec 1973 r. \\
\hline 106. & 165 & kolorowa & kwiecień-maj 1973 r. \\
\hline 107. & 166 & kolorowa & czerwiec-sierpień 1973 r. \\
\hline 108. & 167 & kolorowa & wrzesień-październik 1973 r. \\
\hline 109. & 168 & kolorowa & listopad-grudzień 1973 r. \\
\hline 110. & 169 & kolorowa & styczeń-marzec 1974 r. \\
\hline 111. & 170 & kolorowa & kwiecień-maj 1974 r. \\
\hline 112. & 171 & kolorowa & czerwiec-lipiec 1974 r. \\
\hline 113. & 172 & kolorowa & sierpień $1974 \mathrm{r}$. \\
\hline 114. & 173 & kolorowa & styczeń-marzec 1976 r. \\
\hline 115. & 174 & kolorowa & kwiecień-maj 1976 r. \\
\hline 116. & 175 & kolorowa & czerwiec-sierpień 1976 r. \\
\hline 117. & 176 & kolorowa & wrzesień-październik 1976 r. \\
\hline 118. & 177 & kolorowa & listopad-grudzień $1976 \mathrm{r}$. \\
\hline 119. & 178 & brązowa & styczeń-maj 1977 r. \\
\hline 120. & 179 & kolorowa & czerwiec-grudzień $1977 \mathrm{r}$. \\
\hline 121. & 180 & kolorowa & styczeń-kwiecień 1978 r. \\
\hline 122. & 181 & kolorowa & maj-wrzesień $1978 \mathrm{r}$. \\
\hline 123. & 182 & kolorowa & październik-grudzień 1978 r. \\
\hline 124. & 183 & brązowa & styczeń-maj (do 27) 1979 r. \\
\hline 125. & 184 & kolorowa & czerwiec (od 2) - grudzień 1979 r. \\
\hline 126. & 185 & szara & $\begin{array}{l}\text { Uzupełnienia: luty, kwiecień, maj, czerwiec, lipiec, } \\
\text { październik grudzień } 1979 \text { r. }\end{array}$ \\
\hline 127. & 186 & Szara & Uzupełnienia: styczeń-kwiecień 1980 r. \\
\hline 128. & 187 & szara & Uzupełnienia: maj-lipiec 1980 r. \\
\hline 129. & 188 & Szara & Uzupełnienia: sierpień-wrzesień 1980 r. \\
\hline 130. & 189 & Szara & Uzupełnienia: październik-grudzień 1980 r. \\
\hline 131. & 190 & Szara & Uzupełnienia: styczeń-marzec 1981 r. \\
\hline 132. & 191 & Szara & Uzupełnienia: kwiecień-maj 1981 r. \\
\hline
\end{tabular}


Brakuje w zasobie archiwum kazań za następujący okres: wrzesień 1974 r. grudzień 1975 r. (prawdopodobnie 6-7 teczek), natomiast za okres od stycznia do 1980 do śmierci prymasa zbiór jest niepełny. Brakujące teczki z kazaniami znajdują się w Instytucie Prymasowskim Kardynała Stefana Wyszyńskiego w Warszawie na Choszczówce.

Dwie teczki mają oprawę brązową; nie zostało sprawdzone, czy należały one do jednej z dwu serii, czy też do jeszcze innej.

Zawartość teczek obu serii nie jest jednakowa. Do tej pory skolacjonowałem jedynie pierwsze teczki z obu serii (rok 1955 i 1956). Dla porównania dodałem odniesienia do publikacji Stefan kardynat Wyszyński. Dzieła zebrane, tom II i III ${ }^{12}$.

Tabela 7. Zestawienie zawartości SP 392/60 (szara), SP 392/104 (kol.) i Dziel zebranych.

\begin{tabular}{|c|c|c|c|c|c|}
\hline L.p. & Tytul & Datacja & Kol. & Szara & Dzieła \\
\hline 1 & 2 & 3 & 4 & 5 & 6 \\
\hline 1. & Rozważania nad miską & $1955-1956$ & - & $x$ & - \\
\hline 2. & $\begin{array}{l}\text { Listy Prymasa Polski z Komańczy do bi- } \\
\text { skupa Z. Golińskiego }\end{array}$ & $1955-1956$ & - & $x$ & t. 2 \\
\hline 3. & $\begin{array}{l}\text { Listy Prymasa Polski z Komańczy do ks. } \\
\text { Bronisława Dąbrowskiego - Dyrektora Wy- } \\
\text { działu Spraw Zakonnych }\end{array}$ & $1955-1956$ & - & $\times$ & t. 2 \\
\hline 4. & [list do ojca z 2.02.1956] & 2.02 .1956 & - & $\times$ & - \\
\hline 5. & [list do ojca z 16.03.1956] & 16.03.1956 & - & & - \\
\hline 6. & Odpowiedź ojca na życzenia ks. prałata & 12.05 .1956 & - & & - \\
\hline 7. & $\begin{array}{l}\text { Odnowienie Ślubów Narodu na Jasnej } \\
\text { Górze }\end{array}$ & $12 / 16.05 .1956$ & $\times$ & $\times$ & t. 2 \\
\hline 8. & $\begin{array}{l}\text { Listy z więzienia do Generała OO. Pauli- } \\
\text { nów na Jasnej Górze }\end{array}$ & $\begin{array}{c}31.05,24.06 \\
3.08 .1956\end{array}$ & $\times$ & - & t. 2 \\
\hline 9. & $\begin{array}{l}\text { Adoracje stanowe na uroczystość } \\
\text { 26.08.1956: dla kapłanów }\end{array}$ & I poł. 08.1956 & $x$ & - & t. 2 \\
\hline 10. & $\begin{array}{l}\text { Adoracje stanowe na uroczystość } \\
\text { 26.08.1956: dla Ojców, }\end{array}$ & I poł. 08.1956 & $x$ & - & t. 2 \\
\hline 11. & $\begin{array}{l}\text { Adoracje stanowe na uroczystość } \\
\text { 26.08.1956: dla Matek }\end{array}$ & I poł. 08.1956 & $x$ & - & t. 2 \\
\hline 12. & $\begin{array}{l}\text { Adoracje stanowe na uroczystość } \\
\text { 26.08.1956: dla Młodzieży }\end{array}$ & I poł. 08.1956 & $\times$ & - & t. 2 \\
\hline 13. & Apel do Duchowieństwa & 08.1956 & $x$ & - & t. 2 \\
\hline 14. & $\begin{array}{l}\text { Komentarze do Jasnogórskich Ślubów Na- } \\
\text { rodu: Naród pełen Łaski i Prawdy }\end{array}$ & 09.1956 & $\times$ & - & \\
\hline 15. & $\begin{array}{l}\text { Komentarze do Jasnogórskich Ślubów Na- } \\
\text { rodu: W obronie życia nienarodzonych }\end{array}$ & 09.1956 & $x$ & - & t. 2 \\
\hline 16. & $\begin{array}{l}\text { Komentarze do Jasnogórskich Ślubów Na- } \\
\text { rodu: Małżeństwo katolickie potężną wię- } \\
\text { zią Narodu }\end{array}$ & 09.1956 & $x$ & - & t. 2 \\
\hline
\end{tabular}

${ }^{12}$ Stefan kardynał Wyszyński, Prymas Polski. Dzieła zebrane, tom II (1953-1956), Warszawa 1995; tom III (1956-1957), Warszawa 1999. 


\begin{tabular}{|c|c|c|c|c|c|}
\hline 1 & 2 & 3 & 4 & 5 & 6 \\
\hline 17. & $\begin{array}{l}\text { Komentarze do Jasnogórskich Ślubów Na- } \\
\text { rodu: Pokój Boży w rodzinie polskiej }\end{array}$ & 09.1956 & $\times$ & - & t. 2 \\
\hline 18. & $\begin{array}{l}\text { Komentarze do Jasnogórskich Ślubów Na- } \\
\text { rodu: Młode pokolenie w wierności Chry- } \\
\text { stusowi }\end{array}$ & 09.1956 & $x$ & - & t. 2 \\
\hline 19. & $\begin{array}{l}\text { Komentarze do Jasnogórskich Ślubów Na- } \\
\text { rodu: Kroczyć za Słońcem Sprawiedliwości }\end{array}$ & 09.1956 & $x$ & - & t. 2 \\
\hline 20. & $\begin{array}{l}\text { Komentarze do Jasnogórskich Ślubów Na- } \\
\text { rodu: Bój z wadami narodowymi }\end{array}$ & 09.1956 & $\times$ & - & t. 2 \\
\hline 21. & $\begin{array}{l}\text { List Prymasa Polski z Komańczy do piel- } \\
\text { grzymki wyższych przełożonych zgroma- } \\
\text { dzeń zakonnych żeńskich na Jasną Górę } \\
\text { 15.09.1956 (wyjątek) }\end{array}$ & 15.09 .1956 & - & $x$ & - \\
\hline 22. & $\begin{array}{l}\text { Niepokalany rycerz Boga żywego. Szkic } \\
\text { kazania na 8.12.1956 }\end{array}$ & $\begin{array}{c}\text { przed } \\
28.10 .1956\end{array}$ & $\times$ & $\times$ & t. 2 \\
\hline 23. & List pasterski po powrocie $\mathrm{z}$ więzienia & 28.10 .1956 & $x$ & - & t. 3 \\
\hline 24. & $\begin{array}{l}\text { Spotkania z Panią Jasnogórską po latach do- } \\
\text { świadczeń. Jasna Góra, Cudowna Kaplica }\end{array}$ & 2.11 .1956 & - & $x$ & t. 3 \\
\hline 25. & $\begin{array}{l}\text { „Kamienie węgielne budowania na górach } \\
\text { świętych”. Pierwsze słowa prymasa Polski } \\
\text { na Jasnej Górze po uwolnieniu }\end{array}$ & 2.11 .1956 & $\times$ & - & t. 3 \\
\hline 26. & Jasna Góra, kaplica Matki Bożej & 3.11 .1956 & - & $x$ & - \\
\hline 27. & $\begin{array}{l}\text { Przemówienia do przedstawicieli klasztoru } \\
\text { Niepokalanowa, dzieci oraz rodziców z pa- } \\
\text { rafii niepokalanowskiej }\end{array}$ & 4.11 .1956 & $x$ & - & - \\
\hline 28. & $\begin{array}{l}\text { „Pełnią Prawa jest miłość”, (fragmen- } \\
\text { ty kazania na podstawie tekstu ze „Słowa } \\
\text { Powszechnego”) - Warszawa, kościół Św. } \\
\text { Krzyża }\end{array}$ & 4.11 .1956 & $x$ & $x$ & t. 3 \\
\hline 29. & $\begin{array}{l}\text { „Odsłaniam wam tajemnice...”- przemó- } \\
\text { wienie podczas akademii w seminarium du- } \\
\text { chownym w Łodzi. }\end{array}$ & $\begin{array}{c}6 \text { lub } \\
8.11 .1956\end{array}$ & $x$ & $x$ & t. 3 \\
\hline 30. & Kazanie w kościele akademickim, Lublin & 11.11 .1956 & $\times$ & $\times$ & - \\
\hline 31. & $\begin{array}{l}\text { Prośby Prymasa do młodych. Do młodzieży } \\
\text { KUL, Lublin, aula KUL }\end{array}$ & 11.11 .1956 & $x$ & $x$ & t. 3 \\
\hline 32. & $\begin{array}{l}\text { Gniezno wita swego Prymasa po wyjściu } \\
\text { z więzienia; Gniezno, bazylika NMP, } \\
\text { 14.11.1956 (streszczenie wg „Słowa Po- } \\
\text { wszechnego”) }\end{array}$ & 14.11 .1956 & $x$ & $x$ & - \\
\hline 33. & $\begin{array}{l}\text { Streszczenie egzorty - Gniezno, kaplica se- } \\
\text { minaryjna, }\end{array}$ & 16.11 .1956 & $x$ & $\times$ & - \\
\hline
\end{tabular}

${ }^{a}$ W serii „kolorowej” tekst znajduje się pośród tekstów grudniowych według daty 8 grudnia. 


\begin{tabular}{|c|c|c|c|c|c|}
\hline 1 & 2 & 3 & 4 & 5 & 6 \\
\hline 34. & $\begin{array}{l}\text { Przemówienie z okazji jubileuszu matki } \\
\text { Elżbiety Czackiej (streszczenie) - Laski }\end{array}$ & 18.11 .1956 & $x$ & $x$ & - \\
\hline 35. & $\begin{array}{l}\text { Do wiernych (szkic kazania) - Warszawa, } \\
\text { Wizytki }\end{array}$ & 21.11 .1956 & $x$ & $x$ & - \\
\hline 36. & $\begin{array}{l}\text { Przemówienie do zakonnic w uroczystość } \\
\text { św. Cecylii - Warszawa, Tamka }\end{array}$ & 22.11 .1956 & $x$ & $x$ & - \\
\hline 37. & $\begin{array}{l}\text { Przemówienie do wiernych (ze „Słowa Po- } \\
\text { wszechnego”) - Warszawa, Bazylika Serca } \\
\text { Jezusowego }\end{array}$ & 25.11 .1956 & $x$ & $x$ & - \\
\hline 38. & $\begin{array}{l}\text { Zadzierajcie główki do prawdy! Rozsze- } \\
\text { rzajcie serca miłością". Przemówienie do } \\
\text { dzieci - Warszawa, Bazylika Serca Jezuso- } \\
\text { wego }\end{array}$ & 25.11 .1956 & $x$ & $x$ & t. 3 \\
\hline 39. & $\begin{array}{l}\text { Uroczystości Cecyliańskie (fragmenty ka- } \\
\text { zania ze Słowa Powszechnego) - Warsza- } \\
\text { wa, katedra }\end{array}$ & 25.11 .1956 & $\times$ & $x$ & - \\
\hline 40. & $\begin{array}{l}\text { [List okólny do członków Towarzystwa } \\
\text { Przyjaciół KUL] }\end{array}$ & 25.11 .1956 & - & $x$ & t. 3 \\
\hline 41. & $\begin{array}{l}\text { I ogólnopolska pielgrzymka lekarzy - Jasna } \\
\text { Góra }\end{array}$ & 2.12 .1956 & $x$ & - & t. 3 \\
\hline 42. & $\begin{array}{l}\text { I ogólnopolska pielgrzymka lekarzy - Jasna } \\
\text { Góra, Kaplica, słowo po Mszy św. }\end{array}$ & 2.12 .1956 & $x$ & - & t. 3 \\
\hline 43. & $\begin{array}{l}\text { I ogólnopolska pielgrzymka lekarzy - Jasna } \\
\text { Góra, wykład }\end{array}$ & 2.12 .1956 & $x$ & - & t. 3 \\
\hline 44. & $\begin{array}{l}\text { „Bądźcie radością Kościoła i Ojczyzny!”. } \\
\text { Do nowo wyświęconych kapłanów }\end{array}$ & 8.12 .1956 & $x$ & $x$ & t. 3 \\
\hline 45. & List pasterski w sprawie nauki religii & {$[8.12 .1956]$} & $\times$ & - & t. 3 \\
\hline 46. & $\begin{array}{l}\text { W powstającym z gruzów domu Bożym... } \\
\text { (z notatek) - Warszawa, św. Jakuba }\end{array}$ & 9.12 .1956 & $x$ & $x$ & t. 3 \\
\hline 47. & $\begin{array}{l}\text { Kazanie do wiernych „Tyś jest, czyli inne- } \\
\text { go mamy czekać?” - Warszawa, św. Karola } \\
\text { Boromeusza }\end{array}$ & 9.12 .1956 & $x$ & $x$ & t. 3 \\
\hline 48. & $\begin{array}{l}\text { „Kościół społecznością życia”. [Kazanie ] } \\
\text { Do wiernych - Warszawa, Szembeka [ko- } \\
\text { ściół pw. Niepok. Serca NMP] }\end{array}$ & 9.12 .1956 & $x$ & $x$ & t. 3 \\
\hline 49. & $\begin{array}{l}\text { [Kazanie] Do wiernych - Warszawa, Okę- } \\
\text { cie }\end{array}$ & 10.12.1956 & $x$ & $x$ & - \\
\hline 50. & $\begin{array}{l}\text { Program pielgrzymów stolicy. Do uczestni- } \\
\text { ków pielgrzymek na Jasną Górę - Warsza- } \\
\text { wa, OO Paulini }\end{array}$ & 16.12 .1956 & $\times$ & $x$ & t. 3 \\
\hline 51. & $\begin{array}{l}\text { Kazanie do wiernych - Bydgoszcz [kościół } \\
\text { pw. św. Wincentego] }\end{array}$ & {$[19.12 .1956]$} & $x$ & - & t. 3 \\
\hline 52. & $\begin{array}{l}\text { „Potrzeba, aby obok Syna człowieczego } \\
\text { występowała i Matka Jego”. Na zakończe- } \\
\text { nie } 40 \text {-godzinnego nabożeństwa - Warsza- } \\
\text { wa. Św. Andrzeja Boboli }\end{array}$ & & $\times$ & - & - \\
\hline
\end{tabular}




\begin{tabular}{|c|l|c|c|c|c|}
\hline $\mathbf{1}$ & \multicolumn{1}{|c|}{$\mathbf{2}$} & $\mathbf{3}$ & $\mathbf{4}$ & $\mathbf{5}$ & $\mathbf{6}$ \\
\hline 53. & $\begin{array}{l}\text { Życzenia na Boże Narodzenie: Prymas Pol- } \\
\text { ski do Polaków w kraju i za granicą }\end{array}$ & 21.12 .1956 & $\times$ & $\times$ & t. 3 \\
\hline 54. & $\begin{array}{l}\text { Orędzie o trzeźwym spędzaniu Świąt } \\
\text { z 25.11.1956 }\end{array}$ & 24.12 .1956 & $\times$ & $\times$ & t. 3 \\
\hline 55. & $\begin{array}{l}\text { Ż̇yczenia na Boże Narodzenie dla Polonii } \\
\text { Amerykańskiej - radiostacja WWOL, } \\
\text { Buffalo] }\end{array}$ & 25.12 .1956 & $\times$ & - & t. 3 \\
\hline 56. & Kazanie na Pasterce & 25.12 .1956 & - & $\times$ & - \\
\hline 57. & $\begin{array}{l}{[\text { kazanie] do wiernych, Warszawa, kościół }} \\
\text { św. Szczepana }\end{array}$ & 25.12 .1956 & $\times$ & $\times$ & - \\
\hline 58. & $\begin{array}{l}\text { Do wychowanek Sióstr Felicjanek } \\
\text { (w kościele), Wawer }\end{array}$ & 26.12 .1956 & $\times$ & $\times$ & t. 3 \\
\hline 59. & $\begin{array}{l}\text { Do wychowanek Sióstr Felicjanek (na sali), } \\
\text { Wawer }\end{array}$ & 30.12 .1956 & $\times$ & - & t. 3 \\
\hline
\end{tabular}

W Dziełach Zebranych znajdują się też kazania, listy i rozważania autora, których w ogóle nie ma w teczkach Kazania Prymasa Polski, np. listy do paulina o. Jerzego Tomzińskiego, przeora Jasnej Góry (t 2, s. 185-189), do ks. Michała Kliszki (t. 2, s. 190-196), ks. Jana Czerniaka (t. 2, 197-202) i in. Z drugiej strony w publikacji brak niektórych wystąpień prymasa, zachowanych w maszynopisie, np. kazań i przemówień z Gniezna z dni 14-16. XI oraz z Warszawy (25 i 26. XII 1956 r.). Przyjęto bowiem zasadę publikowania tylko wystąpień autoryzowanych. Dodatkowo niektóre kazania/przemówienia mają datę różną o kilka dni od tej, którą zanotowano w maszynopisie.

\section{Jednostki nieopracowane}

Do opracowania pozostaje 6,5 mb życzeń z lat 1953-1981, dziewięć ksiąg pamiątkowych, trzy teczki listów pasterskich Episkopatu Polski 1945-1974 r., spis wystąpień (w tym kazań) z lat 1946-1958 i 1960-1962 (przekazany w $1987 \mathrm{r}$. przez Instytut Prymasowski), teczki tematyczne, np. listy, dotyczące książki Duch pracy ludzkiej ${ }^{13}$, wizyty kard. Griffina w Polsce, wizyty Prymasa w Mariazell, wycinki prasowe, zgłoszenia na pogrzeb.

Tabela 8. Księgi pamiątkowe.

\begin{tabular}{|c|l|c|}
\hline L.p. & \multicolumn{1}{|c|}{ Zawartość księgi pamiątkowej } & Rok \\
\hline $\mathbf{1}$ & \multicolumn{1}{|c|}{$\mathbf{2}$} & $\mathbf{3}$ \\
\hline 1. & $\begin{array}{l}\text { Hołd Duchowieństwa i alumnów gnieźnieńskich z okazji powrotu Pry- } \\
\text { masa z więzienia }\end{array}$ & 1956 \\
\hline 2. & Prezent na jubileusz - parafia NSPJ w Warszawie & 1961 \\
\hline 3. & Zaproszenie do parafii Nieborów (obecnie diec. łowicka) & 1971 \\
\hline 4. & Zaproszenie od Polonii kanadyjskiej & 1972 \\
\hline 5. & Dar jubileuszowy parafii pw. św. Brygidy w Gdańsku & 1973 \\
\hline
\end{tabular}

${ }^{13}$ S. Wyszyński, Duch pracy ludzkiej. Konferencje o pracy, Włocławek 1946. 


\begin{tabular}{|c|l|c|}
\hline $\mathbf{1}$ & \multicolumn{1}{|c|}{$\mathbf{2}$} & $\mathbf{1}$ \\
\hline 6. & $\begin{array}{l}\text { Dar jubileuszowy kapłanów archidiecezji warszawskiej - uczestników } \\
\text { pielgrzymki do Kalwarii Zebrzydowskiej }\end{array}$ & 1973 \\
\hline 7. & Podziękowania b. ucznia z Włocławka F. Galewicza & 1974 \\
\hline 8. & Dar jubileuszowy parafii Janikowo (arch. gnieźnieńska) & 1974 \\
\hline 9. & Pośmiertna księga hołdu żołnierzy WP i AK & $1981-1982$ \\
\hline
\end{tabular}

Razem ze spuścizną przechowywanych jest $1,5 \mathrm{mb}$ dokumentów, dotyczących uprawnień in spiritualibus: facultates benedicendi, przywileje odpustowe, binacje i trynacje oraz kilka teczek, zatytułowanych: „Korespondencja, na którą J.E. odpowiedział obrazkami". Zasadniczo te dwa rodzaje jednostek archiwalnych zostaną dołączone do zespołu Archiwum Prymasa Polski.

Nie jest to jednak wszystko, co Archiwum Archidiecezjalne w Gnieźnie posiada po Prymasie Tysiąclecia. Ordynariusz otrzymywał bowiem liczne albumy ze zdjęciami, obrazującymi jego posługę duszpasterską w różnych miejscach Polski - jednostki te były już za jego życia sukcesywnie włączane do kolekcji o nazwie „Albumy” (oznaczenie: Al). Posiadamy też wiele nieopracowanych luźnych zdjęć, które sam Prymas przekazywał do archiwum na ręce ks. W. Zientarskiego, np. zdjęcia z wizyt we Włoszech. Zabezpieczono też kilka zdjęć, które wisiały w oprawach w rezydencji prymasowskiej w Gnieźnie. Ponadto przez wiele lat archiwum przechowywało przedmioty, należące niegdyś do kardynała Wyszyńskiego, tj. sutannę i obuwie domowe. Pamiątki te trafiły do Muzeum Archidiecezji Gnieźnieńskiej.

\section{Podsumowanie}

Archiwum Archidiecezjalne w Gnieźnie posiada dużo materiałów archiwalnych po Stefanie kard. Wyszyńskim, prymasie Polski. Część z nich, wytworzonych $\mathrm{w}$ wyniku zarządu archidiecezją gnieźnieńską przez prymasa jako ordynariusza, została już wiele lat temu włączona do zespołu archiwalnego Archiwum Kurii Metropolitalnej. Wiele lat temu zostały również włączone do ewidencji albumy ze zdjęciami, obrazujące posługę prymasa w różnych miejscach Polski. W roku 2014 rozpoczęło się opracowanie właściwej spuścizny po kard. S. Wyszyńskim. Wstępnie wyodrębniono trzy serie dokumentacji: zapiski Pro memoria (oryginalne rękopisy i kopie maszynopisowe), Kazania Prymasa Polski (maszynopisy z wszelkiego rodzaju wystapieniami publicznymi) oraz varia (dotychczas zaliczono do tej serii trzy jednostki). Po uzyskaniu kopii włączymy je do serii Kazania Prymasa Polski i planujemy opracowanie 6,5 mb życzeń, a także ksiąg pamiątkowych i materiałów, odnoszących się do pogrzebu kardynała. Zdjęcia, przechowywane luzem, zostaną włączone do kolekcji albumów.

Część archiwaliów, a mianowicie 1,5 mb dokumentów, wynikających z uprawnień Prymasa in spirutualibus oraz kilka teczek, zatytułowanych: „Korespondencja, na którą J.E. odpowiedział obrazkami” zostanie w przyszłości włączona do zespołu Archiwum Prymasa Polski. Stanie się to jednak dopiero po zamknięciu prac nad archiwaliami po prymasie A. Hlondzie. 
Prace inwentaryzacyjne zaowocowały kontaktami z zespołem dr hab. Pawła Skibińskiego z Warszawy oraz Instytutem Prymasowskim Stefana Kardynała Wyszyńskiego. Wymiana informacji i doświadczeń daje nadzieję na coraz pełniejsze poznanie Wyszynscianów. Wobec spodziewanej beatyfikacji Prymasa Tysiąclecia prace tych trzech środowisk stanowią swoisty hołd wobec Człowieka, którego dzieło i osoba winny być coraz lepiej znane i poważane.

\title{
SPUŚCIZNA PO PRYMASIE STEFANIE KARDYNALE WYSZYŃSKIM W ARCHIWUM ARCHIDIECEZJALNYM W GNIEŹNIE. ZAWARTOŚĆ I STAN OPRACOWANIA
}

\begin{abstract}
Streszczenie
Archiwum Archidiecezjalne w Gnieźnie posiada liczne materiały archiwalne po Stefanie kard. Wyszyńskim, prymasie Polski. Część z nich została włączona do zespołu archiwalnego Archiwum Kurii Metropolitalnej. W roku 2014 rozpoczęło się opracowanie spuścizny po kard. S. Wyszyńskim. Wyodrębniono trzy serie dokumentacji: zapiski Pro memoria (oryginalne rękopisy i kopie maszynopisowe), Kazania Prymasa Polski (maszynopisy z wszelkiego rodzaju wystąpieniami publicznymi) oraz varia (dotychczas zaliczono do tej serii trzy jednostki). Do opracowania zostają życzenia, a także księgi pamiątkowe i materiały dotyczące pogrzebu kardynała. Zdjęcia przechowywane luzem, zostaną włączone do kolekcji albumów. Dokumenty wynikających z uprawnień Prymasa in spirutualibus oraz kilka teczek, zatytułowanych: „Korespondencja, na którą J. E. odpowiedział obrazkami” zostanie w przyszłości włączona do zespołu Archiwum Prymasa Polski.
\end{abstract}

Słowa kluczowe: Stefan Wyszyński; Archiwum Archidiecezjalne w Gnieźnie; archiwalia prymasa Wyszyńskiego; Archiwum Prymasa Polski; Archiwum Kurii Metropolitalnej; Pro memoria Prymasa Wyszyńskiego; Kazania Prymasa Polski

\section{THE LEGACY OF PRIMATE CARDINAL STEFAN WYSZYŃSKI IN THE ARCHDIOCESAN ARCHIVE IN GNIEZNO. THE CONTENT AND THE STAGE OF ITS DESCRIPTION AND CATALOGUING}

\begin{abstract}
Summary
The Archdiocesan Archive in Gniezno has a number of archival materials connected with Cardinal Stefan Wyszyński, the Primate of Poland. Some of them, produced during primate's management of the Archdiocese of Gniezno as an ordinary bishop, were included many years ago into the archival fonds called the Archive of the Metropolitan Curia. In addition, many years ago, the albums with photos showing the Primate's work in many
\end{abstract}


parts of Poland were included into the records. However, the description and cataloguing of the proper legacy of the Primate of the Millenium began in 2014. In the beginning, the documentation was divided into three series: notes 'Pro memoria' (original manuscripts and typed copies), 'The Primate of Poland's Sermons' (typescripts with different kinds of public speeches) and Varia (three units have been included into this series so far). Inventory work on the sermons was halted due to the gaps which we hope to fill with the copies coming from the fonds of the Cardinal Stefan Wyszyński Institute. When we receive the copies, we will include them into the series 'The Primate of Poland's Sermons', then we will begin describing and cataloguing 6,5 linear metres of wishes as well as visitors' books and material relating to the funeral. The loose photos will be included in the collection of the albums.

Some archival materials, 1,5 linear metres of documents, which were produced as a result of Primate's powers in spirutualibus and a few folders entitled 'The correspondence to which His Eminence responded with pictures' will be included in the fonds 'The Primate of Poland Archive' as soon as the work on the archival materials related to Primate Hlond is completed.

The inventory work resulted in the contacts with Dr Hab. Paweł Skibiński from Warsaw and the Primate Cardinal Stefan Wyszyński Institute. The exchange of information and experiences gives hope that Wyszynsciany (material related to Cardinal Wyszyński) will be better known. The beatification of the Primate of the Millenium is approaching, and the work of these three teams is homage paid to the Man whose work and personality should be better known and esteemed.

Keywords: Stefan Wyszyński; the Archdiocesan Archive in Gniezno; Primate Wyszyński's archival materials; the Primate of Poland Archive; the Archive of the Metropolitan Curia; Primate Wyszyński's Pro memoria; The Primate of Poland's Sermons 